\title{
Determination of Nickel and Iron Carbonyl in Carbon Monoxide by ICP-MS Methods and a Pyrex Gas Washing System
}

\author{
Ze-Yi ZHOU ${ }^{1 . a,{ }^{*}}$, Li XIE ${ }^{2, b}$ and Zhe BI ${ }^{3, c}$ \\ ${ }^{1}$ National Institute of Metrology, Beisanhuan Donglu No.18, Beijing 100013, China. \\ ${ }^{2}$ National Institute of Metrology, Beisanhuan Donglu No.18, Beijing 100013, China \\ ${ }^{3}$ National Institute of Metrology, Beisanhuan Donglu No.18, Beijing 100013, China \\ aemail: zhouzy@nim.ac.cn, bemail:xieli@nim.ac.cn, cemail:bizhe@nim.ac.cn \\ ${ }^{\star}$ Corresponding author
}

Keywords: Nickel carbonyl, Iron carbonyl, ICP-MS, Pyrex Gas Washing System

\begin{abstract}
Determination of traces of metals in gases is achieved by using a combination of a Pyrex Gas Washing System and ICP-MS methods. A special purge and blank installation is designed to clean the system with purified Helium (6N). Three 125-ml bubbler tubes in series with a $20 \mathrm{ml}$ of nitric acid ( $20 \%$ ) are used to capture the metals carbonyl in carbon monoxide. The metals dissolved in nitric acid are analyzed by ICP-MS (Agilent 7500ce). This method is able to achieve detection limits down to $1 \times 10^{-10} \mathrm{~mol} / \mathrm{mol}$. Theoretically, the detection limits could go lower, but they are typically limited due to sample contamination. The experimental results show that this method provides a cost-effective approach to measure the traces of metals in gases quickly and accurately.
\end{abstract}

\section{Introduction}

Determination of traces of metals $\left(10^{-9} \sim 10^{-12}\right) \mathrm{mol} / \mathrm{mol}$ in gases is a routine and important task in many fields. Existence of traces of metals in gases will affect quality of many products, especially in semiconductor manufactories. However, metals are almost present in all gases and it is very difficult to obtain a "standard" gas containing absolutely "zero" metals. Meanwhile, fast determination of the traces of metals in gases with high accuracy is especially necessary when reactive standard mixtures gases are involved. As such, development of a rapid, less sample consuming, cost effective and more precise method to detect traces of metals in gases is the focus of this paper.

There are some ways to determine traces of metals carbonyl in gases. However, most of them are either qualitative or semi-quantitative methods due to limitations of the conventional effective and reliable calibration methods using the standard traces of metals mixtures gases, especially when these mixtures are almost impossible to prepare in the required concentrations. The determination of traces of metals carbonyl in carbon monoxide is introduced in this paper by using the combination of a Pyrex Gas Washing System and ICP-MS methods (Abbreviated: PGWS-ICP-MS). The experimental results show that this method can be used to determine simultaneously most of traces of metals carbonyl in carbon monoxide.

\section{Experimental}

\section{Reagents and Equipment}

Reagent: Water, double-distilled and de-ionized. Nitric acid, 70\% (w/v) $\mathrm{HNO}_{3}$, redistilled in glass. Nitric acid, 20\% (w/v) $\mathrm{HNO}_{3}$, was prepared by adding $1428 \mathrm{ml}$ of $70 \%$ (w/v) $\mathrm{HNO}_{3}$ to distilled water followed by dilution to $5000 \mathrm{ml}$. Nickel and Iron stock solutions, i.e. $\left[\mathrm{Ni}^{2+}\right]=100 \mu \mathrm{g} / \mathrm{ml}$, and $\left[\mathrm{Fe}^{3+}\right]=100 \mu \mathrm{g} / \mathrm{ml}$ respectively were prepared by dissolving $0.1000 \mathrm{~g}$ pure $\mathrm{Ni}$ and $0.1000 \mathrm{~g}$ pure Fe in minimum volume of $70 \% \mathrm{HNO}_{3}$, followed by dilution to $100 \mathrm{ml}$ with $20 \%(\mathrm{w} / \mathrm{v}) \mathrm{HNO}_{3}$. Fresh calibration stock solution, with $\mathrm{Ni}=50 \mathrm{ng} / \mathrm{ml}$, and $\mathrm{Fe}=\mathrm{ng} / \mathrm{ml}$ was prepared by diluting $0.5 \mathrm{ml}$ Nickel and Iron stock solution $(100 \mu \mathrm{g} / \mathrm{ml})$ to $1000 \mathrm{ml}$ in a volumetric flask with $20 \% \mathrm{HNO}_{3}$ on a week basis. 
Helium (6N), high purity purging gas in cylinder with a two-stage regulator. The blank of 2\% (w/v) nitric acid for Fe is $11 \mathrm{ng} / \mathrm{ml}$ and for $\mathrm{Ni}$ is $0.61 \mathrm{ng} / \mathrm{ml}$, respectively.

Equipment: 1. Sampler: Pyrex Gas Washing System (see figure 1). 2. Pressure reduce regulator, coarse metering valve, flow meter, wet test meter, stopwatch, cylinders. 3. ICP-MS, Aglient 7500ce, limit of detection, for Fe is $0.01 \mathrm{ng} / \mathrm{g}$, and for $\mathrm{Ni}$ is $0.03 \mathrm{ng} / \mathrm{g}$.

\section{Process and Calculation}

Experimental installation is constructed according to Fig.1. Before the three $125 \mathrm{ml}$ bubbler tubes (7 in series in figure 1) filled with $20.0 \mathrm{ml}$ of nitric acid ( 20\%), the high purity helium (6N) is used to purge the system completely, usually $1 \sim 2$ hours, then with a three ways valve switch to carbon monoxide cylinder (the sample, 5N). In the sample line, the flow rate is fixed at $500 \mathrm{ml} / \mathrm{min}$, the tubing diameter is $3.2 \mathrm{~mm}$ and the height of the acid the gas need to penetrate through is $3 / 4$ of the solution level. The bubble size is about $(1 \sim 3) \mathrm{mm}^{3}$,.The metals carbonyl in carbon monoxide are captured in three bubbler tubes (numbered 1, 2 and 3), and move to the volumetric flasks in series As1, $\mathrm{A}_{\mathrm{s} 2}$ and $\mathrm{A}_{\mathrm{s} 3}$. The flasks are washed thoroughly to collect droplets from aerosols in the parts of the bubbler tubes and tubing, with the wash-out being diluted to $200 \mathrm{ml}$ with double-distilled and de-ionized water by ICP-MS measurement. The blanks (A0i) are prepared the same way as sampling except for using high purity Helium (6N purging gas) instead of carbon monoxide. The results can be calculated with the following equations:

$$
\begin{aligned}
& \gamma_{N i(F e)}=\frac{n_{N i(F e)}}{n_{g a s}}=\frac{\frac{m_{N i(F e)}}{M_{N i(F e)}}}{\frac{p V}{R T}}=\frac{\frac{C_{N i(F e)} V_{s o l}}{M_{N i(F e)}}}{\frac{p V t}{R T}}=\frac{V_{s o l} R T}{M_{N i(F e)} p V} \cdot \frac{C_{N i(F e) ~}}{t} \\
& C_{N i(F e)}=C_{s 1}+C_{s 2}+C_{s 3}-C_{01}-C_{02}-C_{03}
\end{aligned}
$$

Where $\gamma_{\mathrm{Fe}(\mathrm{Ni})}$, as the Ni carbonyl or Fe carbonyl relative quantity in carbon monoxide, $\mathrm{mol} / \mathrm{mol}$. $\mathrm{C}$ as the mass concentrations of the element of interest in solution A, which is determined by ICP-MS and then multiplied by 10 (dilution rate), $\mathrm{ng} / \mathrm{ml}$. $\mathrm{V}_{\text {sol }}=20 \mathrm{ml}$ as volume of the absorption solutions. $\mathrm{V}$ $=0.5 \mathrm{dm}^{3} / \mathrm{min}$ as the flow rate, $\mathrm{t}$ as the time, min. $\mathrm{p}$ with unit $\mathrm{Pa}$ as the ambient pressure during the sampling. $\mathrm{T}$ with unit $\mathrm{K}$ as the ambient temperature during sampling. $\mathrm{R}$ as gas constant with unit $8.314 \mathrm{kPa}$ dm3/K.mol. $\mathrm{M}$ as the molecular weight of $\mathrm{Ni}(\mathrm{CO})_{4}(170.74)$ or $\mathrm{Fe}(\mathrm{CO})_{5}(195.90)$.

\section{Results and Discussion}

In the experiments, the sampling time of bubbler tubes is $20 \mathrm{~min}, 40 \mathrm{~min}$ and $60 \mathrm{~min}$ respectively, three replicates are done for each experiment except that only one measurement is carried out for the blanks. The experimental results are list in table 1 . The linear plot of different sample time (t) vs. the ICP-MS response values (c) is shown in figure 2 and figure 3. The ICP-MS calibration standard curves are shown in Fig. 4 and Fig.5. Table 2 lists the results of relative quantities in $\mathrm{nmol} / \mathrm{mol}$ for $\mathrm{Ni}$ carbonyl and Fe carbonyl in carbon monoxide. 


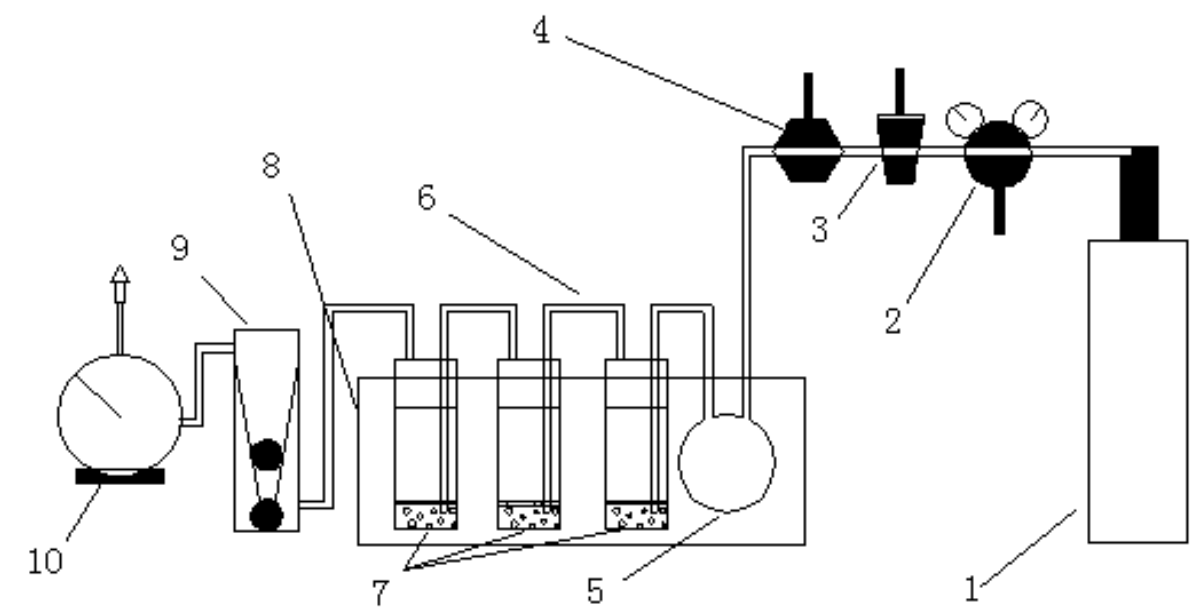

Fig. 1 Pyrex Gas Washing System

1.Cylinder 2.Regulator 3.Coarse metering valve (stainless steel connections) 4.Fine metering valve (10 PSIG Relief valve) 5.Surge flask 6.Polyflo tubing 7.Three bubbler tubes with an impinger train 8.Plexiglas box 9.Flow meter 10.Wet test meter

Table 1. Results of ICP-MS, ng/ml

\begin{tabular}{|c|c|c|c|c|c|c|c|}
\hline \multirow{2}{*}{\multicolumn{2}{|c|}{$\begin{array}{l}\text { Time } \\
\text { ICP-MS }\end{array}$}} & \multicolumn{3}{|c|}{$\mathrm{t}=20 \mathrm{~min}, \mathrm{n}=3, \mathrm{~F}=500 \mathrm{ml} / \mathrm{min}, r_{1 s t}$} & \multicolumn{3}{|c|}{$\mathrm{t}=40 \mathrm{~min}, \mathrm{n}=3, \mathrm{~F}=500 \mathrm{ml} / \mathrm{min}, \Upsilon_{2 \mathrm{sec}}$} \\
\hline & & $\mathrm{C}_{\mathrm{s} 1}-\mathrm{C}_{01}$ & $\mathrm{C}_{\mathrm{s} 2}-\mathrm{C}_{02}$ & $\mathrm{C}_{\mathrm{s} 3}-\mathrm{C}_{03}$ & $\mathrm{C}_{\mathrm{s} 1}-\mathrm{C}_{01}$ & $\mathrm{C}_{\mathrm{s} 2}-\mathrm{C}_{02}$ & $\mathrm{C}_{\mathrm{s} 3}-\mathrm{C}_{03}$ \\
\hline \multirow{6}{*}{$\mathrm{Fe}$} & 1 & 130.6-90.1 & 100.3-90.8 & $92.2-91.3$ & 179.6-92.9 & $110.2-94.7$ & 93.4-95.0 \\
\hline & 2 & 138.0-90.1 & 103.7-90.8 & $90.7-91.3$ & 188.3-92.9 & 108.3-94.7 & $96.2-95.0$ \\
\hline & 3 & 135.4-90.1 & 102.8-90.8 & 92.3-91.3 & 190.4-92.9 & $117.0-94.7$ & $94.2-95.0$ \\
\hline & Average & 134.7-90.1 & 102.3-90.8 & $91.7-91.3$ & 186.1-92.9 & $111.8-94.7$ & $94.6-95.0$ \\
\hline & $\mathrm{RSD}, \%\left(\mathrm{c}_{\mathrm{si}}\right)$ & 2.8 & 1.7 & 1.0 & 3.0 & 4.1 & 1.5 \\
\hline & $\sum_{i=1}^{3}\left(\bar{c}_{s i}-\bar{c}_{0 i}\right) \times 20$ & \multicolumn{3}{|l|}{1130} & \multicolumn{3}{|l|}{2198} \\
\hline \multirow{6}{*}{$\mathrm{Ni}$} & 1 & 8.36-1.17 & $3.20-1.21$ & 2.11-1.19 & $17.8-1.24$ & $4.01-1.29$ & 2.56-1.38 \\
\hline & 2 & $9.45-1.17$ & $3.11-1.21$ & 2.05-1.19 & $16.5-1.24$ & $4.08-1.29$ & 2.78-1.38 \\
\hline & 3 & 8.13-1.17 & $3.79-1.21$ & $1.86-1.19$ & $18.0-1.24$ & $3.90-1.29$ & 2.69-1.38 \\
\hline & Average & $8.65-1.17$ & $3.37-1.21$ & 3.37-1.19 & $17.43-1.24$ & $4.00-1.29$ & $2.68-1.38$ \\
\hline & $\mathrm{RSD}, \%\left(\mathrm{c}_{\mathrm{si}}\right)$ & 8.2 & 10.9 & 6.5 & 4.8 & 2.3 & 4.1 \\
\hline & $\sum_{i=1}^{3}\left(\bar{c}_{s i}-\bar{c}_{0 i}\right) \times 20$ & \multicolumn{3}{|l|}{10.45} & \multicolumn{3}{|l|}{20.20} \\
\hline \multicolumn{2}{|c|}{ Time } & \multicolumn{6}{|c|}{$\mathrm{t}=60 \mathrm{~min}, \mathrm{n}=3, \mathrm{~F}=500 \mathrm{ml} / \mathrm{min}, \Upsilon_{3 r d}$} \\
\hline \multicolumn{2}{|c|}{ ICP-MS } & $\mathrm{C}_{\mathrm{s} 1}-\mathrm{C}_{01}$ & $\mathrm{C}_{\mathrm{s} 2}-\mathrm{C}_{02}$ & $\mathrm{C}_{\mathrm{s} 3}-\mathrm{C}_{03}$ & & & \\
\hline $\mathrm{Fe}$ & 1 & $119.2-96.7$ & $119.2-96.7$ & $96.6-93.5$ & & & \\
\hline
\end{tabular}




\begin{tabular}{|c|c|c|c|c|}
\hline & 2 & $120.4-96.7$ & $120.4-96.7$ & 97.3-93.5 \\
\hline & 3 & 119.4-96.7 & 119.4-96.7 & $96.7-93.5$ \\
\hline & Average & 119.7-96.7 & 119.7-96.7 & 96.9-93.5 \\
\hline & $\mathrm{RSD}, \%\left(\mathrm{c}_{\mathrm{si}}\right)$ & 0.5 & 0.5 & 0.4 \\
\hline & $\sum_{i=1}^{3}\left(\bar{c}_{s i}-\bar{c}_{0 i}\right) \times 20$ & 3852 & & \\
\hline \multirow{6}{*}{$\mathrm{Ni}$} & 1 & 23.12-1.39 & 4.69-1.42 & $3.01-1.37$ \\
\hline & 2 & 21.02-1.39 & $4.23-1.42$ & $3.20-1.37$ \\
\hline & 3 & 20.19-1.39 & $4.88-1.42$ & $2.89-1.37$ \\
\hline & Average & 22.44-1.39 & $5.10-1.42$ & $3.03-1.37$ \\
\hline & $\mathrm{RSD}, \%\left(\mathrm{c}_{\mathrm{si}}\right)$ & 8.9 & 2.4 & 5.2 \\
\hline & $\sum_{i=1}^{3}\left(\bar{c}_{s i}-\bar{c}_{0 i}\right) \times 20$ & \multicolumn{3}{|l|}{28.23} \\
\hline
\end{tabular}

Table 2 Ni carbonyl and Fe carbonyl relative quantities in carbon monoxide, $\mathrm{nmol} / \mathrm{mol}$.

\begin{tabular}{|c|c|c|c|c|}
\hline \multicolumn{2}{|l|}{ Time } & $\begin{array}{l}\mathrm{t}=20 \mathrm{~min}, \mathrm{n}=3 \\
\mathrm{~F}=500 \mathrm{ml} / \mathrm{min}\end{array}$ & $\begin{array}{l}\mathrm{t}=40 \mathrm{~min}, \mathrm{n}=3, \mathrm{~F}=500 \\
\mathrm{ml} / \mathrm{min}\end{array}$ & $\begin{array}{l}\mathrm{t}=60 \mathrm{~min}, \mathrm{n}=3, \mathrm{~F}=500 \\
\mathrm{ml} / \mathrm{min}\end{array}$ \\
\hline \multirow{5}{*}{$\mathrm{Fe}(\mathrm{CO})_{5}$} & $\Upsilon_{\mathrm{Fe} 1}$ & 11.2 & 11.1 & 13.4 \\
\hline & $\Upsilon_{\mathrm{Fe} 2}$ & 13.4 & 12.2 & 14.2 \\
\hline & $\Upsilon_{\mathrm{Fe} 3}$ & 12.9 & 13.1 & 14.8 \\
\hline & Average & 12.5 & 12.1 & 14.1 \\
\hline & RSD, \% & 9.2 & 8.3 & 5.0 \\
\hline \multicolumn{5}{|c|}{ Total average and RSD, \%: C=12.9 nmol $/ \mathrm{mol}, \mathrm{RSD}=9.6 \%$} \\
\hline \multirow{5}{*}{$\mathrm{Ni}(\mathrm{CO})_{4}$} & $\Upsilon_{\mathrm{Ni1}}$ & 2.59 & 2.63 & 2.31 \\
\hline & $\Upsilon_{\mathrm{Ni} 2}$ & 2.83 & 2.50 & 2.42 \\
\hline & $\Upsilon_{\mathrm{Ni3}}$ & 2.62 & 2.65 & 2.51 \\
\hline & Average & 2.68 & 2.59 & 2.42 \\
\hline & RSD, \% & 4.9 & 3.2 & 4.2 \\
\hline
\end{tabular}




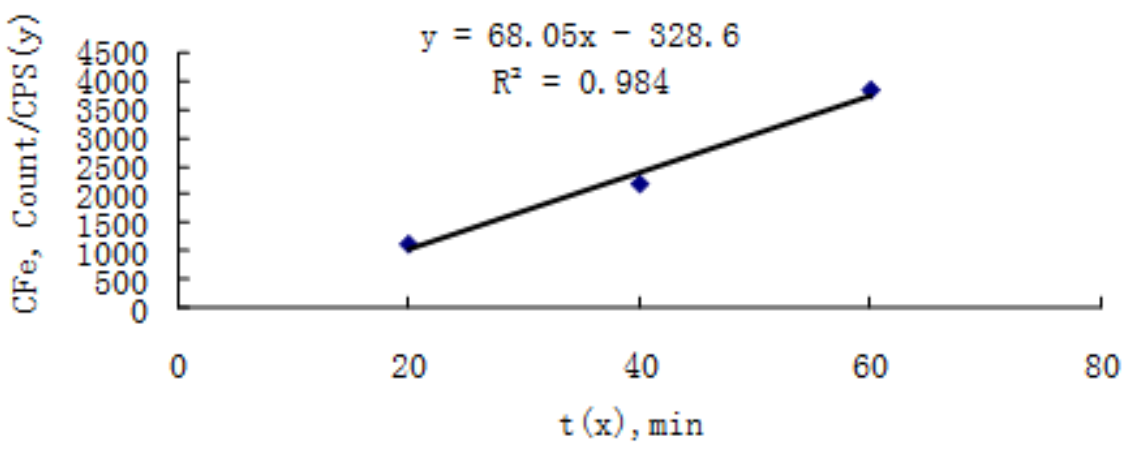

Fig.2. ICP-MS response linearity for Fe via absorption time

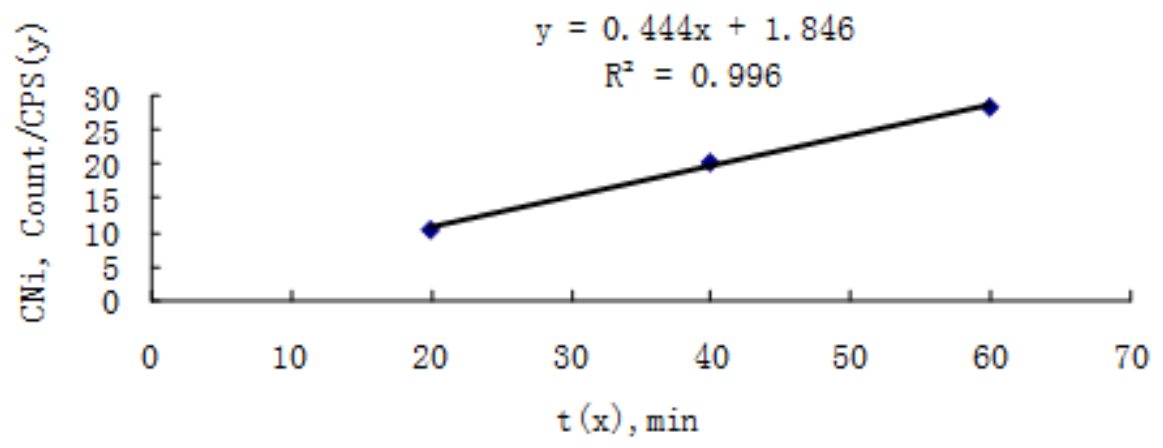

Fig.3. ICP-MS response linearity for Fe Ni absorption time

From table 1, Fig. 2 and Fig.3, it is clear that the bubbler tube in the third position has few metals collected in nitric acid (20\%) with most of metals collected in the first bubbler tube and a few of them collected in the second bubbler tube. The repeatability of the bubblers tubes collections is within $11 \%$. The linearity of ICP-MS response values (c) and sample time (t) are satisfying in this method $\left(\mathrm{R}^{2}>0.98\right)$. As we noticed the blank concentration of $\mathrm{Fe} \approx 90 \mathrm{ng} / \mathrm{ml}$ seems large for ICP-MS, implying that it might come from the high purity purging gas Helium (used as blank purging gas) and stainless steel valves in the sample line.

From the results in table 2 it is clear that the stability of the determination results $\quad(\mathrm{RSD}<11 \%$ ) good enough. The relative standard deviation is within $10 \%$ from different sample time, which is much better than those of other methods reported.

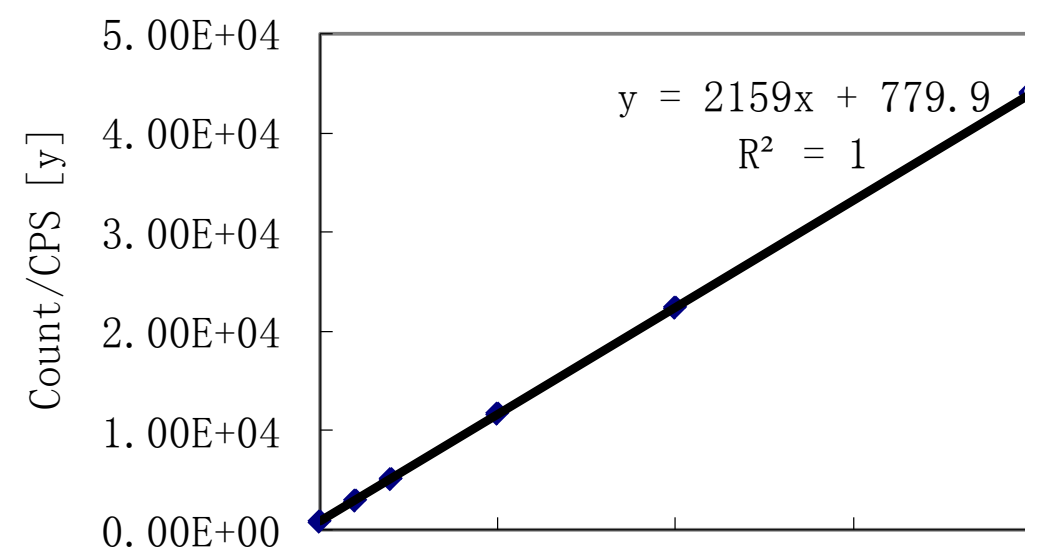

Fig. 4 ICP-MS calibration standard curve of $\mathrm{Ni}$ (concentrations range: $0 \sim 20 \mathrm{ng} / \mathrm{ml}$ ) 


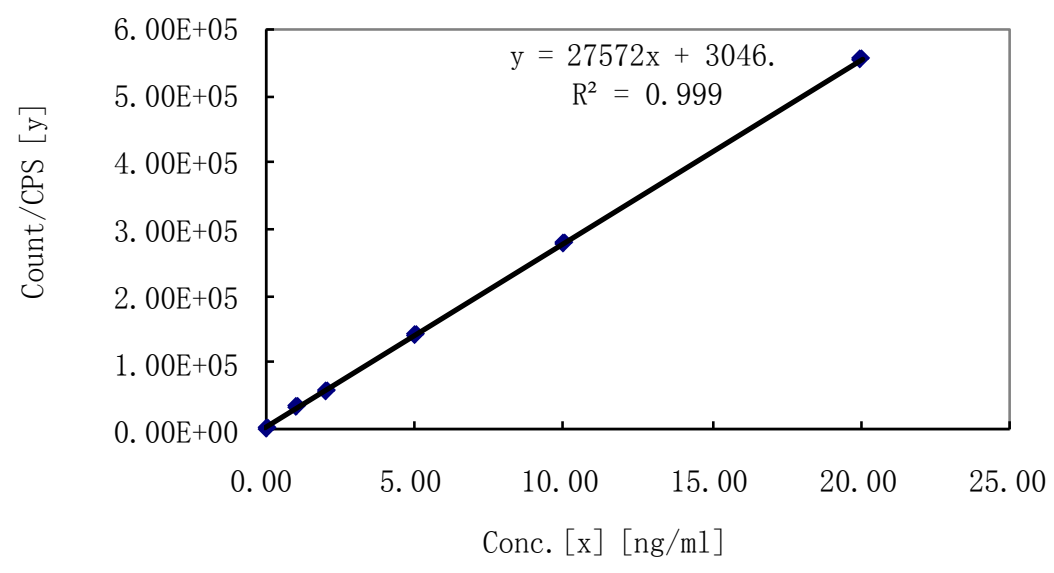

Fig. 5 ICP-MS calibration standard curve of Fe (concentrations range: 0 20 ng/ml)

\section{Uncertainty Estimation}

From equation (1), the uncertainty budget for the determination of the metals carbonyl in carbon monoxide with PGWS-ICP-MS is given in table 3. The uncertainty components have been combined according to GUM. The budget is calculated for a typical temperature $295.15 \mathrm{~K}$ and a typical pressure $112 \mathrm{kPa}$. The measurement $\mathrm{Ni}$ carbonyl $\Upsilon_{1 s t}$ is selected as an example to estimate the method uncertainty. The principal components of the uncertainty budget are as follows:

-ICP-MS response value c: The standard deviation of the $\mathrm{c}_{\mathrm{si}}$ and $\mathrm{c}_{0 \mathrm{i}}$ for Ni carbonyl $\Upsilon_{1 \mathrm{st}}$ are 0.51 $\mathrm{ng} / \mathrm{ml}$ and $0.02 \mathrm{ng} / \mathrm{ml}$ respectively. According to the normal probability distribution, the standard uncertainties are $0.30 \mathrm{ng} / \mathrm{ml}$ and $0.012 \mathrm{ng} / \mathrm{ml}$ respectively. The calibration solution uncertainties for the instrument ICP-MS are $0.2 \mathrm{ng} / \mathrm{ml}$ for both $\mathrm{Ni}$ and Fe calibration stock solution, which leads to a standard uncertainty $0.1 \mathrm{ng} / \mathrm{ml}$.

-Temperature: we corrected the temperature probe reducing its measurement uncertainty down to $0.1 \mathrm{~K}$. However, a maximum temperature change during the sampling time of $0.3 \mathrm{~K}$ is recorded. Assuming a rectangular probability distribution, it leads to a standard uncertainty of $0.17 \mathrm{~K}$.

-Pressure: the pressure transducer has been calibrated with a state of relative uncertainty of $\pm 0.05 \%$ of full scale. Assuming these are the upper and lower boundaries of a rectangular probability distribution, it corresponds to a standard uncertainty of $3.2 \mathrm{kPa}$. Furthermore, the measurement performed during this study have confirmed that the difference of pressure has a maximum $0.5 \mathrm{kPa}$, leading to an additional uncertainty of $(0.25 / \sqrt{3})=0.2 \mathrm{kPa}$ in the pressure measurement.

-Sample volume: sample volume can be calculated by flow rate $\mathrm{F}(\mathrm{dm} 3 / \mathrm{min})$ and sample time $\mathrm{t}$ (min). Correcting the flow meter reduces its measurement uncertainty to $0.003 \mathrm{dm} 3 / \mathrm{min}$. The sample time uncertainty is estimated as $0.002 \mathrm{~min}$.

-Volume of absorption solution: assuming a rectangular probability distribution, the uncertainty of the volume of absorption solution of $0.2 \mathrm{ml}$, leads to a standard uncertainty of $0.12 \mathrm{ml}$.

-Dilution uncertainty: assuming a rectangular probability distribution, the uncertainty of the volume of volumetric flask of $0.2 \mathrm{ml}$, leads to a standard uncertainty of $0.12 \mathrm{ml}$.

-Gas constant: the uncertainty can be ignored in this study.

-Molecular weight: the uncertainty can be ignored in this study. 
Table 3. Uncertainty budget for the determination of the Ni carbonyl in carbon monoxide with PGWS-ICP-MS

\begin{tabular}{|c|c|c|c|c|c|c|}
\hline \multirow[b]{2}{*}{$\begin{array}{l}\text { Components } \\
\text { (y) }\end{array}$} & \multicolumn{4}{|c|}{ Uncertainty u(y) } & \multirow[b]{2}{*}{$\begin{array}{l}\text { Sensitivity } \\
\text { coefficient } \\
e_{i}=\partial \gamma / \partial y\end{array}$} & \multirow[b]{2}{*}{$\begin{array}{l}\text { Contributio } \\
\mathrm{n} \text { to u(Y) } \\
\left|e_{i}\right| \cdot u\left(y_{i}\right)\end{array}$} \\
\hline & Source & $\begin{array}{l}\text { Distributio } \\
\mathrm{n}\end{array}$ & $\begin{array}{l}\text { Standard } \\
\text { uncertaint } \\
\mathrm{y}\end{array}$ & $\begin{array}{l}\text { Combined } \\
\text { standard } \\
\text { uncertaint } \\
\text { y u(y) }\end{array}$ & & \\
\hline \multirow{2}{*}{$\begin{array}{l}\text { ICP-MS } \\
\text { response } \\
\text { value } \mathrm{C}_{\mathrm{si}}\end{array}$} & $\begin{array}{l}\text { Repeatabilit } \\
\mathrm{y}\end{array}$ & Normal & $0.30 \mathrm{ng} / \mathrm{ml}$ & \multirow{2}{*}{$0.32 \mathrm{ng} / \mathrm{ml}$} & \multirow{2}{*}{0.26} & \multirow{2}{*}{0.083} \\
\hline & $\begin{array}{l}\text { Calibration } \\
\text { standard }\end{array}$ & Rectangular & $0.10 \mathrm{ng} / \mathrm{ml}$ & & & \\
\hline \multirow{2}{*}{$\begin{array}{l}\text { ICP-MS } \\
\text { response } \\
\text { value } \mathrm{c}_{0 \mathrm{i}}\end{array}$} & $\begin{array}{l}\text { Repeatabilit } \\
\mathrm{y}\end{array}$ & Normal & $\begin{array}{l}0.012 \\
\mathrm{ng} / \mathrm{ml}\end{array}$ & \multirow[t]{2}{*}{$0.10 \mathrm{ng} / \mathrm{ml}$} & \multirow[t]{2}{*}{0.26} & \multirow[t]{2}{*}{0.026} \\
\hline & $\begin{array}{l}\text { Calibration } \\
\text { standard }\end{array}$ & Rectangular & $0.10 \mathrm{ng} / \mathrm{ml}$ & & & \\
\hline \multirow[b]{2}{*}{$\begin{array}{l}\text { Temperature } \\
\mathrm{T}\end{array}$} & $\begin{array}{l}\text { Temperature } \\
\text { probe }\end{array}$ & Rectangular & $0.30 \mathrm{~K}$ & \multirow[b]{2}{*}{$0.35 \mathrm{~K}$} & \multirow[b]{2}{*}{0.01} & \multirow[b]{2}{*}{0.004} \\
\hline & $\begin{array}{l}\text { Difference } \\
\text { during } \\
\text { sampling }\end{array}$ & Rectangular & $0.17 \mathrm{~K}$ & & & \\
\hline \multirow[b]{2}{*}{ Pressure p } & $\begin{array}{l}\text { Pressure } \\
\text { gauge }\end{array}$ & Rectangular & $3.20 \mathrm{kPa}$ & \multirow[b]{2}{*}{$3.20 \mathrm{kPa}$} & \multirow[b]{2}{*}{-0.02} & \multirow[b]{2}{*}{0.064} \\
\hline & $\begin{array}{l}\text { Difference } \\
\text { during } \\
\text { sampling }\end{array}$ & Rectangular & $0.20 \mathrm{kPa}$ & & & \\
\hline \multirow{2}{*}{$\begin{array}{l}\text { Sample } \\
\text { volume V }\end{array}$} & Flow rate $\mathrm{F}$ & Normal & $\begin{array}{l}0.003 \\
\mathrm{dm}^{3} / \mathrm{min}\end{array}$ & \multirow{2}{*}{$0.003 \mathrm{dm}^{3}$} & \multirow{2}{*}{-5.37} & \multirow{2}{*}{0.016} \\
\hline & $\begin{array}{l}\text { Sampling } \\
\text { time t }\end{array}$ & Rectangular & $0.001 \mathrm{~min}$ & & & \\
\hline $\begin{array}{l}\text { Volume of } \\
\text { absorption } \\
\text { solution } 20.0 \\
\text { ml }\end{array}$ & $\begin{array}{l}\text { Volume } \\
\text { error }\end{array}$ & Rectangular & $0.12 \mathrm{ml}$ & $0.12 \mathrm{ml}$ & 0.14 & 0.017 \\
\hline $\begin{array}{l}\text { Dilution } \\
\text { uncertainty }\end{array}$ & $\begin{array}{l}\text { Volume } \\
\text { error }\end{array}$ & Rectangular & $0.12 \mathrm{ml}$ & $0.12 \mathrm{ml}$ & 1.00 & 0.120 \\
\hline $\begin{array}{l}\text { Gas constant } \\
\mathrm{R}\end{array}$ & Gas constant & Rectangular & 0.00 & 0.00 & 0.33 & 0 \\
\hline $\begin{array}{l}\text { Mole weight } \\
\text { M }\end{array}$ & $\begin{array}{l}\text { Molecular } \\
\text { weight M }\end{array}$ & Rectangular & 0.00 & 0.000 & 0.02 & 0 \\
\hline
\end{tabular}

The combined standard uncertainty of measurement of Ni carbonyl in carbon monoxide is:

$$
u(\gamma)=\sqrt{\sum\left[e_{i} u\left(y_{i}\right)\right]^{2}}=0.15 \mathrm{nmol} / \mathrm{mol}
$$

The total standard uncertainty of measurement of Ni carbonyl in carbon monoxide $(\mathrm{k}=2,95 \%)$ is:

$$
U(\gamma)=k \cdot u(\gamma)=2 \times 0.15 \approx 0.3 \mathrm{nnmol} / \mathrm{mol}
$$

\section{Conclusion}

Recently developed ICP-MS to analyze the trace elements especially for metals in liquid and solid has given a higher sensitivity and higher accuracy than previous instruments did. However, for traces 
of metals in high purity gases, there are few efficient ways available. This study focuses on developing a new practical method with ICP-MS and a Pyrex Gas Washing System. The experimental results show that the method repeatability is less than $11 \%$ with good linearity $\left(\mathrm{R}^{2}>0.98\right)$ and small uncertainty $(\sim 0.3 \mathrm{nmol} / \mathrm{mol}$ for $\mathrm{Ni}$ carbonyl in carbon monoxide with $\mathrm{k}=2,95 \%)$. We believe that this method may meet the requirements of the field analysis.

\section{Acknowledgement}

This project was supported by the Funds of infrastructure condition platform provided by the National Ministry of Science and Technology of China ( Project: 2013BAK12B02). The authors express their sincere thanks to those who helped revising the draft in English.

\section{References}

[1] SL Dong. "Determination of nickel in seawater by carbonyl generation”, Analytical Chemistry, 54(7):1182-1184(2002).

[2] L Liwei, D Hao, W Li, Z Chengbin, H Xiandeng."UV-induced carbonyl generation with formic acid for sensitive determination of nickel by atomic fluorescence spectrometry”,. Talanta, 80(3):1239-1244(2010).

[3] RR Gouman, AJ Kodde, CJ Smit.“Process for removal of hydrogen sulphide, iron pentacarbonyl and nickel tetracarbonyl from a synthesis gas stream”, EP,2011.

[4] M Johansson, J Snell, W Frech, R Hansson. "Determination of nickel using electrochemical reduction and carbonyl generation with in situ trapping electrothermal atomic absorption spectrometry”, 《Analyst》, 123(6):1223-1228(1998).

[5] Eller, P.M. "Determination of Nickel Carbonyl by Charcoal Tube Collection and Furnace Atomic Absorption”, Appl. Ind. Hyg. 1:115-118 (1986).

[6] NIOSH Manual of Analytical Methods, 2nd ed., Vol. 7, P\&CAM 344, U.S. Department of Health and Human Service, Publ. (NIOSH) 82-100 (1982).

[7] Special Occupational Hazard Review and Control Recommendations for Nickel Carbonyl, U.S. Department of Health, Education, and Welfare, Publ. (NIOSH) 77-184 (1977).

[8] Miwa, Satoshi 2002 Apparatus for determination of trace organic substance in gas by FT-IR spectroscopy Jpn. Kokai Tokkyo Koho JP 2002139431 A2(2002). 